\title{
Social Support, Gratitude and Psychological Well- Being of Persons with Disabilities
}

\author{
Amellia Rozza Destyani ${ }^{1}$, Ahmad Fikry Ghazali ${ }^{2}$, Abid Delizea Harizta ${ }^{3}$, and \\ H. Fuad Nashori ${ }^{4}$ \\ \{amelliarozzad@gmail.com¹, a.fikry.ghazali@gmail.com², adelizeah@gmail.com³ \\ ${ }^{1234}$ Department Master of Psychology, Islamic University of Indonesia, Yogyakarta, Indonesia
}

\begin{abstract}
The aim of this studies to know the relationship between gratitude, social support for the psychological well- being of persons with disabilities. Subjects in this study were persons with physical disabilities in Yogyakarta who were of productive years. The sampling technique in this study was purposive sampling with a subject of 56 people. The measurement of this study was done using questionnaire method. The results of data analysis was done using regression analysis technique of two predictors that there is a significant relationship between gratitude and social support for psychological wellbeing in persons with disabilities as indicated by $\mathrm{R}$ value of 0.415 and $\mathrm{F}$ regression of 17.764 with $p<0.01$. There is a significant positive relationship between gratitude and psychological well-being indicated by a significance value of $0.078(\mathrm{p}<0.05)$. Then a very significant positive relationship between social support and psychological wellbeing was indicated by a significance value of $0.708(p>0.05)$.
\end{abstract}

Keywords: Disability, Gratitude, Social Support, Psychological Well-Being

\section{Introduction}

Accessibility is very important for persons with disabilities. Accessibility of persons with disabilities aims to ensure the independence and participation of persons with disabilities in all areas of life in society, not only related to public facilities but also to public services. With accessibility, persons with disabilities can live as a society in general without discrimination. However, the rights of persons with disabilities in Indonesia have not been fully fulfilled.

The rights of persons with disabilities written in the Republic of Indonesia Law No. 8 of 2016, namely (1) the right to life; (2) free from stigma; (3) privacy; (4) justice and legal protection; (5) education; (6) employment, entrepreneurship and cooperatives; (7) health; (8) politics; (9) religion; (10) sports; (11) culture and tourism; (12) social well-being; (13) accessibility; (14) public services; (15) protection from disasters; (16) habilitation and rehabilitation; (17) concessions; (18) data collection; (19) live independently and are involved in the community; (20) expressing, communicating and obtaining information; (21) change place and citizenship; (22) free from acts of discrimination, neglect, torture and exploitation. From a formal legal perspective, persons with disabilities have the right to live well.

If the above rules are implemented properly, the lives of persons with disabilities will be close to ideal, as can be witnessed in European and American countries. Similarly in Indonesia, most European countries that already have regulations in laws that regulate the rights of persons with disabilities. In his research on several universities in various countries 
in Europe and America, Vrăşmaş stated that starting 150 years ago The Gallaudet University had become the first to provide education to deaf people and people with difficulties in hearing [1]. The students who took part in the education level in the university, recorded as of 2013 had reached 1,753 students. This is in line with what was expressed by Connor et al. [2] which stated that in America researchers conducted studies that focus on persons with disabilities including understanding the medical and psychological conditions of persons with disabilities, especially in political, social, cultural, historical factors to understand what is disabilitias meaningfully, and focus on the education assistance of persons with disabilities so that they have the same rights as other normal human beings.

In Indonesia, even though it has been written in the Republic of Indonesia Law concerning persons with disabilities since 1997 [3], in fact up to now the rights of persons with disabilities are not fully fulfilled. Indonesia, including Yogyakarta, has not been effective in fulfilling the rights of persons with disabilities, even though in 2017 there were 26,177 people with disabilities in Yogyakarta listed in the list of people with social well-being problems [4].

Research conducted by Rahayu \& Dewi [5] analyzed public policies and services for people with disabilities in Yogyakarta. The results of the study showed that friendly service programs are not optimal because they are constrained in implementation and the constraints of human resources, budget and community stigma make the implementation of fair public services for persons with disabilities less effective. In addition, public facilities in Yogyakarta have not been entirely disability friendly. Government and private buildings in Yogyakarta, some of which have not been friendly to people with disabilities, such as the absence of guiding blocks and sidewalks that are still widely misused by the community, make access to persons with disabilities hampered. In fact, there are still many school children who have not had the opportunity to go to school and have difficulty accessing health [6]. Jogja City Hall such as main access, information boards that are not accessible for the blind, parking vehicles that are not fully accessible for the physically disabled, the blind and the deaf, as well as the ramp in the Trans Jogja shelter is also considered very unfriendly for persons with disabilities because it is not standard, even there are also not many public servants who understand accessibility [7].

Persons with disabilities are people who have physical, mental, intellectual or sensory limitations in the long-term who when interacting with the environment and people encounter obstacles to participate fully and effectively based on equality of rights [8]. Some types of disabilities include body disability, vision, hearing, speech, psychosocial, mental retardation and chronic diseases [9].

The limited accessibility possessed by persons with disabilities, such as difficulties in carrying out social activities, work activities, household activities and daily activities make persons with disabilities underestimated by the surrounding community because they are considered unproductive and unable to carry out their full duties and responsibilities. This results in persons with disabilities feeling inclined to be ignored [10]. This can affect the psychological well-being of persons with disabilities, such as a more unstable emotional attitude, affect self-confidence and self-acceptance, even if persons with disabilities cannot adjust to their circumstances, there will be psychological problems in the side of affection, moody, feeling insignificant, withdrawing from social situations, tend to blame themselves and the social environment. These things can make people with disabilities stress [11]. In persons with disabilities due to accidents, they feel various psychological effects in the form of trauma, anger, shock, cannot accept the situation, depression and even suicide [12]. 
Psychological well-being is a term used to describe an individual's psychological health based on fulfilling positive psychology function criteria, such as the level of an individual's ability to accept themselves as they are, forming warm relationships with others, being independent of social pressure, controlling the external environment, has meaning in life, and realize its potential continuously [13]. According to Ryff, psychological well-being is a multidimensional thing [14]. There are several dimensions of psychological well-being, namely: 1) individuals can accept all their weaknesses and advantages (self-acceptance); 2) able to foster positive relationships with others (positive relation with others); 3 ) independent (autonomy); 4) able to master the environment in the sense that it can modify the environment to suit its desires (environmental mastery); 5) have a purpose in life; and 6) continue to develop his personality (personal growth) [15].

This paper aims to know the effect of two important variables, in this case gratitude and social support, on psychological well-being. Gratitude is the permission given by Allah in the form of acceptance with the heart after being understood with knowledge and actions both verbally and in deeds [16]. Gratitude is a behavior or trait associated with affection (affective trait), mood and emotions. In general, being grateful is a tendency to recognize and respond to positive experiences obtained from the goodness of others or results obtained with gratitude [17]. Watkin [18] revealed that there is a close relationship between gratitude and the welfare component.

Some studies have proven the link between gratitude and psychological well-being. Dewanto \& Retnowati study found that people with disabilities who are grateful have been shown to have psychological well-being and positive thoughts compared to those who are not grateful [18]. Then the research conducted by Ratnayanti \& Wahyuningrum proved that gratitude contributes $10.37 \%$ to psychological well-being in mothers who have mentally retarded children [19]. In addition, Zulfiana also proved that writing a gratitude letter can increase gratitude for parents with children with special needs [20].

Factors that influence psychological wellbeing, besides gratitude, are social support. Disclosed by Ryff, social support is a factor that affects psychological wellbeing, in addition to demographic factors, evaluation of life experiences; and locus of Control (LOC) [21]. Social support is the individual belief in the availability of support that comes from family, friends and closest people (significant others) when he needs [22]. The existence of social support from the people closest to and people around make the fears and worries experienced by individuals diminish and also lead to a good attitude of self-acceptance [23], [24]. The higher the social support, the better the psychological well-being of a person, on the contrary the lower the social support, the higher the psychological pressure of a person [25].

This is consistent with the research conducted by Hardjo \& Novita that there is a significant positive relationship between social support and psychological well-being in adolescents who are victims of sexual abuse [26]. The same results were also found in the Jarmitia et al. studies that a significant positive relationship between social support and selfconfidence in persons with physical disabilities, where the higher social support, the higher the confidence of persons with physical disabilities [27]. Waqiati et al. also revealed that there was a significant negative relationship between social support and anxiety facing the world of work for disabled people [23]. In addition, the study of Purnaningtyas revealed that external factors of self-acceptance in persons with physical disabilities due to accidents are social support [24].

This research has a difference with previous studies, where this study discusses at the same time three variables, namely gratitude, social support and psychological well-being. In addition, this study also chose persons with disabilities as research subjects. Based on 
previous studies, the researchers rarely found research that discusses gratitude variables or social support variables on psychological well-being, especially for persons with disabilities.

The psychological well-being of persons with disabilities is considered low because of inadequate accessibility and perceptions of people who underestimate that persons with disabilities are considered unproductive, unable to carry out their duties and responsibilities thus persons with disabilities tend to be ignored. Therefore, the purpose of this study is to find out how the relationship between gratitude and social support for the psychological well-being of persons with disabilities. This research is expected to increase knowledge about the psychological well-being of persons with disabilities. The hypothesis of this study is that there is a relationship between gratitude and social support with psychological well-being in persons with disabilities. The higher the gratitude and social support, the higher the psychological well-being of persons with disabilities.

\section{Research Method}

This study used a quantitative approach, namely research that emphasizes data in the form of numbers and then processed by statistical methods [28]. Quantitative research is seen in terms of objectives, this study is used to test a theory, present a fact or describe statistics, and to show relationships between variables [29]. This research is descriptive because it raised facts, circumstances, variables, and phenomena that occur at this time.

The selection of respondents for this study was conducted purposively. The characteristics of the subject were workers with disabilities from birth or not from birth. This study involved 56 respondents who were domiciled in Yogyakarta with productive ages ranging from 15 years - 64 years with both male and female sexes and had at least elementary school education.

The method of data collection was done by using a questionnaire. Psychology welfare questionnaires were collected on a scale adapted from a measurement according to five aspects of, namely self-acceptance, positive relationships with others, independence, selfdevelopment, environmental mastery and life goals [15]. Then the gratitude questionnaire were adapted with four dimensions from Rusdi, which is grateful for knowledge, grateful with heart, grateful with oral, and thankful for actions [16]. While the social support questionnaire was adapted to the Zimet et al. which contained three aspects, namely significant others, family and friends [22]. This study used a trial used with the value of Cronbach alpha reliability: psychological well-being scale of 0.810 , gratitude scale of 0.877 , and social support scale of 0.801 .

This research is correlational research. This correlation study is a relationship between two variables, not only in the form of cause and effect but also reciprocity between two variables [29] thus we will be able to know the relationship between gratitude and social support for psychological well-being of persons with disabilities. 


\section{Research Results}

Based on the results of data analysis it was revealed that social support and gratitude had an influence on the psychological well-being of persons with disabilities. Based on the results of simple linear regression analysis that has been done, obtained $\mathrm{F}$ count value of 17.764 with a significance level of $0.000(\mathrm{p}<0.05)$. This means that there is a relationship between the variables of social support, gratitude and psychological well-being of persons with disabilities. The coefficient that has a positive value shows that there is a positive relationship between the variables of social support and gratitude for the psychological well-being of persons with disabilities. So, the hypothesis proposed "The presence of social support and gratitude influence for the psychological well-being of persons with disabilities" is acceptable. The results of this study indicated that there was a value of R2 obtained by social support and gratitude for psychological wellbeing of 0.415 . This shows that the variables of social support and gratitude provide an effective contribution of $41.5 \%$ towards an increase in psychological wellbeing in persons with disabilities with $58.5 \%$, then the rest can be influenced by other variables not examined. As for more details can be seen in table 1 below:

Table 1. Table of Effective Contribution to Social Support and Gratitude for Psychological Well-being

\begin{tabular}{cc}
\hline Model & RSquared \\
\hline$(\mathrm{X} 1+\mathrm{X} 2) * \mathrm{X} 3$ & 0.415 \\
\hline
\end{tabular}

Effective contribution given by the social support variable on psychological well-being is 0.101 or $10.1 \%$ of the total effective contributions of these two variables, and the effective contribution given by the gratitude variable is 0.357 or $35.7 \%$ of the positive contribution of the two related variables. The effective contribution of the two variables can be seen from table 2 below:

Table 2. Table of Effective contribution to Social Support and Gratitude

\begin{tabular}{cc}
\hline Model & RSquared \\
\hline $\mathrm{X} 1 * \mathrm{X} 3$ & 0.101 \\
$\mathrm{X} 2 * \mathrm{X} 3$ & 0.357 \\
\hline
\end{tabular}

Note :

$\begin{array}{ll}\mathrm{X} 1 & \text { : Social Support } \\ \mathrm{X} 2 & \text { : Gratitude } \\ \mathrm{X} 3 & \text { : Psychological Well-being }\end{array}$

\section{Discussion}

This study proves that there is a positive relationship between social support, gratitude for psychological well-being. This can be proven by looking at the correlation value of 0.645 with a significance value of $0.000(\mathrm{p}<0.01)$, which means that there is a positive relationship between social support, gratitude for psychological well-being, where the higher the level of 
social support and gratitude the higher psychological well-being of persons with disabilities. Social support has an important role in its efforts to improve psychological well-being of an individual, this was revealed by Indrakentjana which stated that there is an influence of social support for psychological well-being, where social support here includes its social functioning including, physical-biological needs, the need to be recognized as a group and society, the need to feel self is considered important and useful, and the need to achieve something useful for him [30]. Tough said that social relations have an important role in the health and mental well-being of persons with disabilities [31]. Social relationships are in the form of high quality relationships and support. In addition, Tahmasbipour \& Taheri also states that students who have good social support will have good mental health [32]. According to Hasan \& Muryantinah said that the existence of social support in increasing motivation in persons with disabilities is more beneficial to their social environment [33]. The same thing with the research conducted by Waqiati et al. where in their study succeeded in revealing that overall there is a significant relationship between social support and self-efficacy towards the anxiety of facing the world of work for disabled people [23].

The same thing is also supported by the results of research from Jarmitia et al. which stated that there is a positive relationship between social support and confidence in people with disabilities [27]. Self-confidence according to Ryff is part of the condition of an individual who has a positive attitude towards himself or others, creates and regulates the surrounding environment to suit his needs, has a purpose in life, and makes life more meaningful in trying to explore and develop selfpotential [14]. The existence of social support makes people with disabilities feel confident and better able to adapt to their physical condition, so that people with disabilities will see their shortcomings as not something that is full of pressure and suffering [30].

Dewanto \& Retnowati stated that the welfare of persons with disabilities in a quantitative and qualitative manner changes [18]. This was proven by the experimental results measured using a scale of negative positive experience and psychological well-being which obtained results that positive thoughts increased significantly after the intervention intervention was carried out compared to the control group. The existence of gratitude to someone will always also improve the quality of life of a person [34]. Therefore, if an individual with a disability gets social support from the surrounding environment, he will not feel discouraged and think negatively. This also applies to grateful individuals, they will be able to think more positively about themselves that they are not differentiated from other individuals.

Based on the explanation above, it can be concluded that the three variables in this study are social support, gratitude and psychological well-being included in the high category. This shows that the subjects in this study have obtained and have a concept of social support and good gratitude.

\section{Conclusion}

Based on the results of data analysis that has been done, it can be concluded that there is a significant positive correlation between gratitude and social support with psychological wellbeing in persons with disabilities. The higher the gratitude and social support for people with disabilities, the higher their psychological well-being. But gratitude has a greater influence than social support for psychological wellbeing, which is equal to $35.7 \%$ while social support is $10.1 \%$. Overall, the effective contribution of gratitude and social support for psychological 
well-being is $41.5 \%$, while the remaining $58.5 \%$ is influenced by other variables not examined. This research can be useful for persons with disabilities and families who have persons with disabilities, with gratitude and social support felt by persons with disabilities will improve their psychological well-being.

As a limitation in this study, it is important for further research for this research. First: For the social environment. The results of the study show that social support contributes to improving the psychological well-being of persons with disabilities. So from that, the social environment around him should always provide support and attention by having a harmonious relationship and providing constructive criticism and suggestions for persons with disabilities..

Second: Suggestions for Research Subjects. The research subject is expected to increase the gratitude possessed. Besides that, as a person with disabilities, the subject of the study is also expected to provide social support to friends with disabilities to be able to provide benefits to others.

For researchers who are interested in researching more about social support, gratitude, and psychological well-being, they are expected to be able to research with a wider range of research subjects, classify the types of disabilities to be examined more specifically and provide an age range that does not have very far differences among research subjects. 


\section{References}

[1] Vrăşmaş, T. Adults with disabilities as students at the university. Procedia - social and behavioral sciences, 142, pp 235-242 (2014)

[2] Connor, D. J., Gabel, S. L., Gallagher, D. J., \& Morton, M. Disability studies and inclusive education - implications for theory, research, and practice. International Journal of Inclusive Education, 12 (5), pp. 441-457 (2008)

[3] Republic of Indonesia Law No. 4 of 1997 with Persons with Physical Defect

[4] Kur \& DIk. Ada 26 Ribu Penyandang disabilitas di DIY yang masuk daftar PMKS, terbanyak di Gunungkidul. http://jogja.tribunnews.com/2017/07/14/ ada-26-ribu-penyandang-disabilitas-di-diyyang-masukdaftar-pmks-terbanyak-di-gunungkidul. Diunduh tanggal 24 Desember 2018. (2017)

[5] Rahayu, S., \& Dewi, U. Pelayanan publik bagi pemenuhan hak-hak disabilitas di Kota Yogyakarta. Natapraja, 1 (1) (2013)

[6] Setiawan, S.D. \& Rahadi, F. 12 September 2018. Fasilitas publik Yogyakarta belum ramahdisabilitas. https://www.republika.co.id/berita/nasional/daerah/18/09 /12/pey04o291- fasilitas-publikyogyakarta-belumramah-disabilitas. Diunduh tanggal 1 Februari 2019

[7] Sunartono. 14 Desember 2018. DIY Masih jauh dari aksesibilitas bagi penyandang disabilitas. https://jogjapolitan.harianjogja.com/read /2018/12/14/510/958909/diy-masih-jauh-dariaksesibilitasbagi-penyandang-disabilitas. Diunduh tanggal 1 Februari 2019

[8] Republic of Indonesia Law No. 8 of 2016 about Persons with Disabilities

[9] Ayuningtyas, D., Misnaniarti, Rayhani, M. Analisis situasi kesehatan mental pada masyarakat di Indonesia dan strategi penanggulangannya. Jurnal Ilmiah Kesehatan Masyarakat, 9 (1), pp. 1- 10 (2018)

[10] Irwanto, Kasim, E.R., Fransiska, A., Lusli, M., \& Siradj, O. Analisis situasi penyandang disabilitas di Indonesia: sebuah desk-review. Pusat Kajian Disabilitas Fisip UI (2010)

[11] Sayyidah, A.N. Dinamika penyesuaian diri penyandang disabilitas di tempat magang kerja (studi deskriptif di balai rehabilitas terpadu penyandang disabilitas (BRTPD) Yogyakarta). INKLUSI, 2 (1), pp. 64-86 (2015)

[12] Puspasari, D., \& Alfian, I.N. Makna hidup penyandang cacat fisik postnatal karena kecelakaan. Jurnal Psikologi Klinis dan Kesehatan Mental, 1 (2), pp. 151-157 (2012)

[13] Ryff, C.D., \& Keyes, C. L. M. The structure of psychological well-being revisited. Journal of Personality and Social Psychology, 69 (4), pp. 719-727. (1995)

[14] Ryff, C.D. Happiness is everything, or is it? exploration on the meaning of psychological wellbeing. Journal of Personality and Social Psychology, 57 (6), pp. 1069-1081. (1989)

[15] Ryff, C.D. Psychological Well-Being in Adult Life. Current Directions in Psychological Science, 4 (4), pp. 99-104 (1995)

[16] Rusdi, A. Syukur dalam psikologi Islam dan konstruksi alat ukurnya. Jurnal Ilmiah Penelitian Psikologi: Kajian Empiris \& Non-Empiris, 2 (2), pp. 37-54 (2016)

[17] McCullough, M.E., Emmons, R.A., \& Tsang, J.A. The grateful disposition: a conceptual and empirical topography. Journal of Personality and Social Psychology, 82 (1), pp. 112-127 (2002)

[18] Dewanto, W., \& Retnowati, S. Intervensi kebersyukuran dan kesejahteraan penyandang disabilitas fisik. Gadjah Mada Journal of Professional Psychology, 1 (1), pp. 33-47. (2015)

[19] Ratnayanti, T.L., \& Wahyuningrum, E.W. Hubungan antara gratitude dengan psychological wellbeing Ibu yang memiliki anak tunagrahita di SLB negeri Salatiga. Satya Widya, 32 (2), pp. 57-64 (2016)

[20] Zulfiana, U. Menulis gratitude letter untuk meningkatkan happiness pada orang tua anak berkebutuhan khusus (ABK). Happiness, 1 (1) (2017)

[21] Ramadhani, T., Djunaedi, \& Atiek, S. Kesejahteraan psikologis (psychological well-being) siswa yang orangtuanya bercerai (studi deskriptif yang dilakukan pada wiswa di SMK negeri 26 Pembangunan Jakarta). Insight: Jurnal Bimbingan Konseling, 5 (1), pp. 108-115 (2016)

[22] Zimet, G. D., Dahlem, N. W., Zimet, S. G., \& Farley, G.K. The multidimensional scale of perceived social support. Journal of Personality Assessment, 52(1), pp. 30-41 (1988) 
[23] Waqiati, H.A., Hardjajani, T., \& Nugroho, A.D. Hubungan antara dukungan sosial dan efikasi diri dengan kecemasan menghadapi dunia kerja pada penyandang tuna daksa. Jurnal Ilmiah Psikologi Candra Jiwa, 2 (1), pp. 1-12 (2013)

[24] Purnaningtyas. Penerimaan diri pada laki-laki dewasa penyandang disabilitas fisik karena kecelakaan. EMPATHY, 2 (1) (2013)

[25] Jibeen, T., \& Khalid, R. Predictors of psychological well-being of Pakistani immigrants in Toronto, Canada. International journal of Intercultural Relations, 34 (5), pp. $452-464$ (2010)

[26] Hardjo, S., \& Novita, E. Hubungan dukungan sosial dengan psychological well-being pada remaja korban sexual abuse. ANALITIKA, 7 (1), pp. 12-19 (2015)

[27] Jarmitia, S., Sulistyani, A., Yulandari, N., Tatar, F.M., \& Santoso, H. Hubungan antara dukungan sosial dengan kepercayaan diri pada penyandang disabilitas fisik di SLB Kota Banda Aceh. Jurnal Psikoislamedia, 1 (1), pp. 61-69 (2016)

[28] Azwar, S. Metode penelitian. Pustaka pelajar: Yogyakarta. (2007)

[29] Subana, M., \& Sudrajat. Dasar-dasar penelitian ilmiah. Pustaka setia: Bandung (2005)

[30] Indrakentjana, B. Pengaruh dukungan sosialterhadap peningkatan keberfungsian sosial penyandang cacat fisik di kecamatan Cikajang Kabupaten Garut. Jurnal Ilmuan Pekerjaan Sosial, 21 (1) (2013)

[31] Tough, H., Siegrist, J., \& Fekete, C. Social relationships, mental health and wellbeing in physical disability: a systematic review. BMC Public Health, 17 (1). (2017)

[32] Tahmasbipour, N., \& Taheri, A. A survey on the relation between social support and mental health in students Shahid Rajaee University. Procedia - Social and Behavioral Sciences, 47, pp. 5-9. (2012)

[33] Hasan, S., \& Muryantinah, M. Hubungan antara dukungan sosial teman sebaya dengan penyesuaian diri siswa tunarungu di sekolah inklusi. Jurnal Psikologi Pendidikan dan Perkembangan, 3 (2), pp. 128-135 (2014)

[34] Putri, D.A., Sukarti, \& Rachmawati, M.A. Pelatihan kebersyukuran untuk meningkatkan kualitas hidup guru sekolah inklusi. Jurnal Intervensi Psikologi, 8 (1), pp. 21-40 (2016)

[35] Brebahama, A., \& Listyandini, R.A. Gambaran tingkat kesejahteraan psikologis penyandang tunanetra dewasa muda. Jurnal Mediapsi, 2 (1),pp. 1-10 (2016)

[36] Nazir, M. Metode penelitian. Penerbit ghalia indonesia: Bogor. (2005) 